\title{
STRUCTURING THE MANAGEMENT SYSTEM AS A FACTOR IN THE INTENSIVE ENTERPRISE DEVELOPMENT
}

\section{Bezus P. I.}

\section{INTRODUCTION}

The long-term economic crisis in Ukraine, which began in 1990, continues to this day. During 28 years of independence, gross domestic product (GDP) reached its minimum value in 2000 (43.2\% of the 1990 level of GDP) and its maximum value in 2008 (74.2\% of the 1990 level of GDP $)^{1}$. To date, this figure has not reached $60 \%$ of the 1990 level of GDP. This indicates the imperfection of the structural adjustment of the domestic economy, the unsatisfactory investment climate and the poor level of market relations. In turn, the success of economic transformations at the macro level depends on the effective activity of specific microeconomic units - producers of gross domestic product ${ }^{2}$. The main task facing the enterprise is its effective economic development, through the intensive use of production potential and improving the management system. Economic development, as a process, may be associated with a change in the nomenclature of the structure of the enterprise, a change in the direction of its activity. But in any case, economic development should be focused on increasing the production of competitive products, increasing efficiency and, as a result, increasing profits.

\section{Resource management system structuring}

Given the limited resources, the method of economic development of economic entities without attracting investments due to the determination and use of reserves for each factor deserves special attention, even a slight decrease in which leads to an increase in the efficiency of the entire enterprise.

\footnotetext{
${ }^{1}$ Статистичний щорічник України за 2016 рік / Державна служба статистики України. Київ : ТОВ «Август Трейд», 2017. 552 с.

2 Безус П.І., Безус А.М. Стратегії економічного розвитку виробничих підприємств. Вісник КНУТД. Серія «Економічні науки». 2016. №2. С. 80-87.
} 
To determine the factors affecting the activities of the enterprise, it is necessary to determine the structure of this production. Based on the connections of the control system with the organization and production systems, the control system is divided into functional parts that correspond to its structure. The enterprise management system consists of two types of management processes. The first type can be defined as the management of the production process, and the second - the management of the organization of production, or the management of the process of providing resources.

The composition of the control system can be represented as follows:

$$
\mathrm{S}=\left\{\mathrm{S}_{\mathrm{P}}, \mathrm{S}_{\mathrm{R}}\right\}
$$

where $S_{P}$ - manufacturing process control system,

$S_{R}$ - resources support process management system.

By V. M. Hlushkov ${ }^{3}$ in the classification of control tasks, the control system can be divided into a Process Control System (PCS) and an Managerial Control System (MCS). The basis of this classification is the nature of the control object. The object of PCS control are technological processes, their parameters, and MCS - organizations of any level and their units.

Despite the importance of the technologies used in the manufacture of products, we restrict ourselves to considering the influence of the organizational management system on improving the efficiency of enterprise production.

We will consider the definition of the structure of the control system on the example of a notional enterprise.

In connection with the taken distribution of the production management system (Formula 1), based on the decomposition method of the management system ${ }^{4}$, the $S_{R}$ resource management subsystem for the enterprise can be divided into smaller elements that should reflect the actual management tasks that correspond to the existing conditions and goals of the given production. Functional subsystems are such elements of the organizational management system. Each management task should be

\footnotetext{
3 Глушков В.М. Макроэкономические модели и принципы построения ОГАС. Москва Статистика, 1975. $250 \mathrm{c.}$

${ }^{4}$ Клименюк Н.Н. Алгоритм декомпозиции систем организационного управления. Исследование операций и АСУ : Республиканский междуведомственный науч. сб., 1985. Вып. 26. С. 97-104.
} 
applied in a certain period of time associated with a specific unit and a specific type of resource.

Thus, the enterprise resource management system is divided into the following functional subsystems:

I. By types of resources. The resource management system consists of a subsystem to ensure the production of the necessary types of resources:

$$
\mathrm{S}_{\mathrm{R}}=\left\{\mathrm{S}_{\mathrm{r}}, r=\overline{1, R}\right\},
$$

where $S_{r}$ - providing production with a resource of the form $r$.

This subsystem by types of necessary resources $(r)$, if we consider such integrated types of resources as labor, material, fixed assets and energy, may consist of the following elements:

- provision of labor resources;

- provision of material resources;

- provision of fixed assets;

- provision of energy resources.

In each of these subsystems, the costs of the corresponding resources are taken into account.

II. By producing departments. Each resource management task should be considered relative to a specific unit. Therefore, each of the particles defined above for the tasks of managing the provision with the named types of resources $\left(S_{r}\right)$ is divided into smaller particles that determine their belonging to a specific production unit:

$$
\mathrm{S}_{\mathrm{r}}=\left\{\mathrm{S}_{\mathrm{rl}}, l=\overline{1, L}\right\}, r=\overline{1, R}
$$

where $S_{r l}$ - subsystems for providing production with a resource of type $r$ in the production unit $l$.

That is, the management task takes a more specific form, since it relates to a specific type of resource, the share of which can be distributed to determine the necessary type of raw material of a given quality, and a specific unit, to a specific site or workplace.

On the example of the production structure of a notional enterprise (Fig. 1), the distribution of the resource management system according to the above mentioned characteristics is shown. Educated management subsystems in accordance with the existing divisions of the enterprise must implement the following tasks:

1. Managing the provision of labor resources $(r=1)$, divided into tasks:

1.1. Enterprise labour force management $(r=1, l=1)$. 
1.2. Workshop labour force management № $1(r=1, l=2)$.

1.8. Managing the provision of work force of the central technological laboratory $(r=1, l=8)$.

2. Managing the provision of material resources $(r=2)$, divided into tasks:

2.1. Management of the provision of material resources of the enterprise $(r=2, l=1)$.

2.8. Material resources management of the central technology laboratory $(r=2, l=8)$.

3. Management of security of fixed assets $(r=3)$, divided into tasks:

3.1. Enterprise fixed assets management $(r=3, l=1)$.

3.8. Management of the provision of fixed assets of the central technological laboratoryï $(r=3, l=8)$.

4. Energy resources management $(r=4)$, divided into tasks:

4.1. Enterprise energy resources management $(r=4, l=1)$.

4.8. Energy resources management of the central technology laboratory $(r=4, l=8)$.

III. By control phases. To control each of the above created parts of the system, it is necessary to carry out a full complex of control phases.

To control the various processes that occur at the enterprise, it is necessary to constantly carry out an interconnected set of control phases representing a closed loop. The management process consists of the following phases: planning, accounting, control and regulation ${ }^{5}$.

The sequence of implementation of each of these phases provides a control process. According to the sign - the control phase, each of the previously obtained particles can be distributed into smaller elements that correspond to the selected control phase:

$$
\mathrm{S}_{\mathrm{rl}}=\left\{\mathrm{S}_{\mathrm{rlf}}, f=\overline{1, \mathrm{~F}}\right\}, r=\overline{1, R}, l=\overline{1, L},
$$

where $S_{r l f}$ - the subsystem of the $f$ control phase, which plans or takes into account, or controls, or regulates (depending on the selected phase) the provision of production with a resource of the form $r$ in the production unit $l$.

\footnotetext{
${ }^{5}$ Менеджмент: експрес-підручник / за аг. ред.. М.М. Клименюка. - К.: Міленіум, 2017. - 174 с.
} 


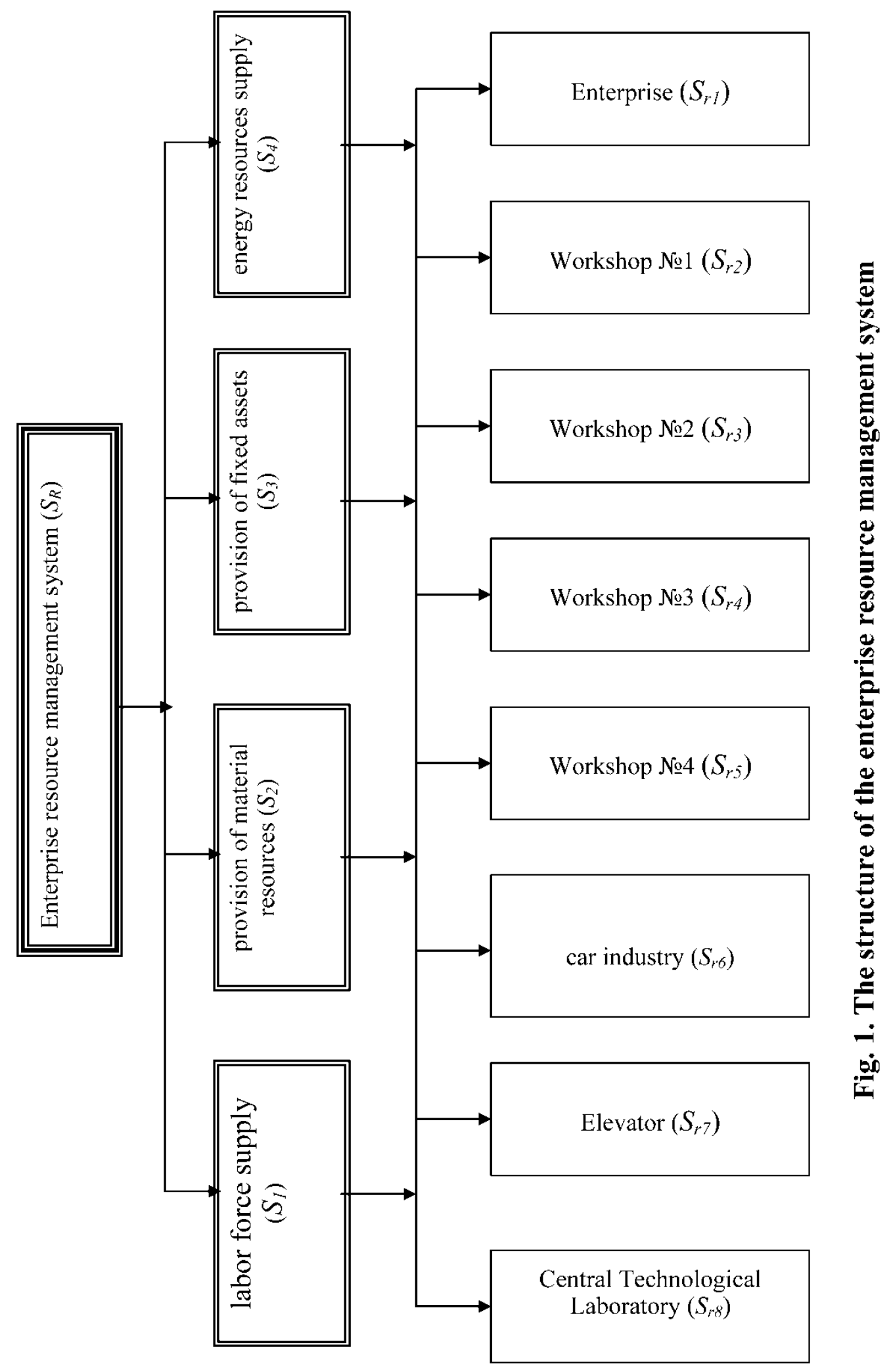


All these management tasks cannot be realized if they are considered in isolation from the time of the implementation of the management process. Therefore, for a complete decomposition of the organizational management system, it is necessary to consider another feature that is associated with the execution time.

IV. By management periods. To solve the management tasks, the following periods can be distinguished: year, quarter, month, decade, week, day, shift.

If $t$ is denoted as the number of the corresponding time period, then the decomposition of the organizational management system allows you to get the following parts:

$$
\mathrm{S}_{\mathrm{rlf}}=\left\{\mathrm{S}_{\mathrm{rlft}}, t=\overline{1, T}\right\}, r=\overline{1, R}, l=\overline{1, L}, f=\overline{1, F} .
$$

Thus, as a result of the decomposition of the system on four grounds, a complete list of tasks for managing the process of providing the enterprise with resources is obtained. Each of these tasks can be represented as an elementary particle of a four-dimensional system, the coordinates of which are controlled processes, production units, control phases, control periods. To solve any management task, it is necessary to name the specific value of all coordinates, for example: providing labor resources (all controlled processes), workshop No. 1 (all production units), accounting (all phases of management), the first quarter (the entire management period).

As a result, you can get such a task - accounting for the provision of labor resources of workshop No. 1 for the first quarter.

So, based on the distribution of the management system (Formula 1), the complete list of tasks for managing the enterprise $M$ consists of a complete list of tasks for managing the production process $M(P)$ and a full list of tasks for managing the provision of resources $M(R)$.

Thus, the number of control tasks can be calculated by the formula:

$$
\mathrm{M}=\mathrm{M}(\mathrm{P})+\mathrm{M}(\mathrm{R})=\mathrm{P} \cdot \mathrm{L} \cdot \mathrm{F} \cdot \mathrm{T}+\mathrm{R} \cdot \mathrm{L} \cdot \mathrm{F} \cdot \mathrm{T},
$$

where $P, R$ - the number of controlled processes in accordance with the production process and the process of providing resources;

$L$ - number of production units;

$F$ - number of control phases;

$T$ - number of control periods. 
The discovered structure of the production management system acts as the basis for determining the reserves for increasing production volumes, as the main factor in the economic development of production.

\section{Efficiency index as an indicator of production intensification}

An effective way to develop production is to intensify it. Despite the fact that studies are being conducted at the macro level to determine indicators of the level of intensification, it is advisable to focus on indicators of the intensity of production at the level of the studied object and its units.

The determination and measurement of production intensity will allow us to quantitatively evaluate various options for improving production in terms of its development and intensification.

If we consider the direction of development of the enterprise, focused on increasing production through the use of its reserves, it is necessary to determine the factors that affect changes in production. The classification of factors existing in the literature, as a rule, depends on the selected features, which are often assigned subjectively, depending on the objectives of the study. The proposed classification of factors makes it possible to analyze all existing factors and identify those of them, the impact on which will lead to a significant increase in production efficiency.

Each management task in the implementation of the production development process should be associated with a continuous determination of its effectiveness.

The economic efficiency of production is determined by the ratio of production results with the costs that led to this effect, that is, production efficiency can be estimated by the following formula ${ }^{6}$ :

$$
E=\frac{Z}{Y},
$$

where $Z$ - the volume of products manufactured by the enterprise for the analyzed period of time;

$Y$ - production costs for the same time period.

Formula (7) can determine the efficiency of a given enterprise for a specified period of time, but does not make it possible to analyze its economic situation, draw conclusions and take measures for its positive changes.

\footnotetext{
${ }^{6}$ Гавва В.Н. Потенціал підприємства: формування та оцінювання. Київ : ЦНЛ, 2004. 224 с.
} 
The definition of efficiency should be based on a system of indicators, and this system of indicators should reflect the structure of the enterprise management system as a whole, which was given above. Based on the considered structure of the enterprise management system, each specific management task has to be evaluated by a corresponding performance indicator.

Management tasks cover a multi-level system of production processes, units, resources, time periods. Therefore, the set of tasks for determining effectiveness should have an identical multi-level structure. Under this condition, the detected structure of the production management system will determine the effectiveness of each production process that is covered by the management system.

Referring to a certain structure of the control system, we note:

$r$-functional subsystem number of resources support,

where $r=1$ - labor resources support process;

$r=2$ - the process of providing production with material resources;

$r=3$ - the process of ensuring production of fixed assets;

$r=4$ - energy resources supply process.

In this case, the resources are divided according to the corresponding resource subsystems: labor, material, fixed assets, energy. But such detalization is not enough. Because, if the possibility of increasing production efficiency as a result of improved management of material resources is established, then this direction is not sufficiently specified, since the company uses several types of material resources. Among them may be those whose use is highly effective. So, among all types of resources involved in the production process, it is necessary to determine those due to which it is possible to increase the efficiency of the entire production. In the same way, the production efficiency of various types of products can vary significantly. The greatest reserves for increasing efficiency are identified when analyzing the production of those types of products for which performance indicators are small. For this, it is necessary to calculate indicators of production efficiency of each type of product.

To indicate the production performance of the enterprise and reflect its hierarchical structure, it is necessary to input the following symbols regarding the classification of business units and management periods: 
$k$-production unit level number, $k=\overline{0, K}$, if $k=0$, then this is the level of the enterprise, (Fig. 2); $k=1$ - second level, for example workshop; $k=2$ - third level, for example, a workshop section;

$n$-number of the production unit of the $k$-th level of the production structure, $n=\overline{1, N_{k}}$, that is, at each $k$ - th level there are $N_{k}$ production units. The pairs of indices $(k, n)$ completely denote each of the production units. For example (1.3) this is unit 3 at the second level of the production structure, that is, in this case (Fig. 2) at the level of workshops, elevator, car fleet and laboratory, namely this is workshop № 3. A pair of indices (0.1) mark the enterprise as a whole. In the same way control periods are indicated, that is, each of them also refers to the corresponding level of the control period structure ( $\tau$ - s the number of the level structure of the control period, $\tau=\overline{0, T}$ ) and up to the period under consideration ( $t$ - is the period number at the $\tau$ - th level, $\left.t=\overline{1, \mathrm{~T}_{\tau}}\right)$. That is, a pair of indices $(\tau t)$ mark the necessary period of time. For example, a pair of indices $0,1-$ mark the year that is being analyzed, and if the quarter is taken as the next level (i.e $\tau=1)$, then the first quarter at this level is assigned the number $1(t=1)$ and the pair of indices that it marks will be 1,1 .

To determine the effectiveness, you must enter the type of product, or assign it the corresponding number $-p, p=\overline{1, P}$. After assigning indices to units and time periods, one can note many types of products produced by the unit $(k, n)$ for a period of time $(\tau, t)-P^{k n t t}$.

Thus, the quantity of products of type $p$, that is manufactured by the unit $(k, n)$ for the period $(\tau, t)$ is indicated as $Z_{p}^{k n t t}$.

Returning to the distribution of resources to subsystems and the definition of certain types of material resources, it is necessary, in addition to the distribution of resources to subsystems $r$, to indicate a resource of a certain type $-i$, where $i=\overline{1, I}$, related to a specific resource subsystem $r, r=\overline{1, R}$.

Certain types and volumes of resources are used to produce a specific type of product. To indicate this, the following quantity is introduced: $I_{p}-$ is the complete score of resources used to produce products of the form $p$. A score of resources refers to the resource subsystem $r$ and is used to produce products of the form $p$ is marked as $I_{r p}$.

Thus, $Y_{r i p}^{k n t}-$ is the amount of resource $i$ of subsystem $r$, spent for the production of products of type $p$ by unit $(k, n)$ for the period $(\tau, t)$. 


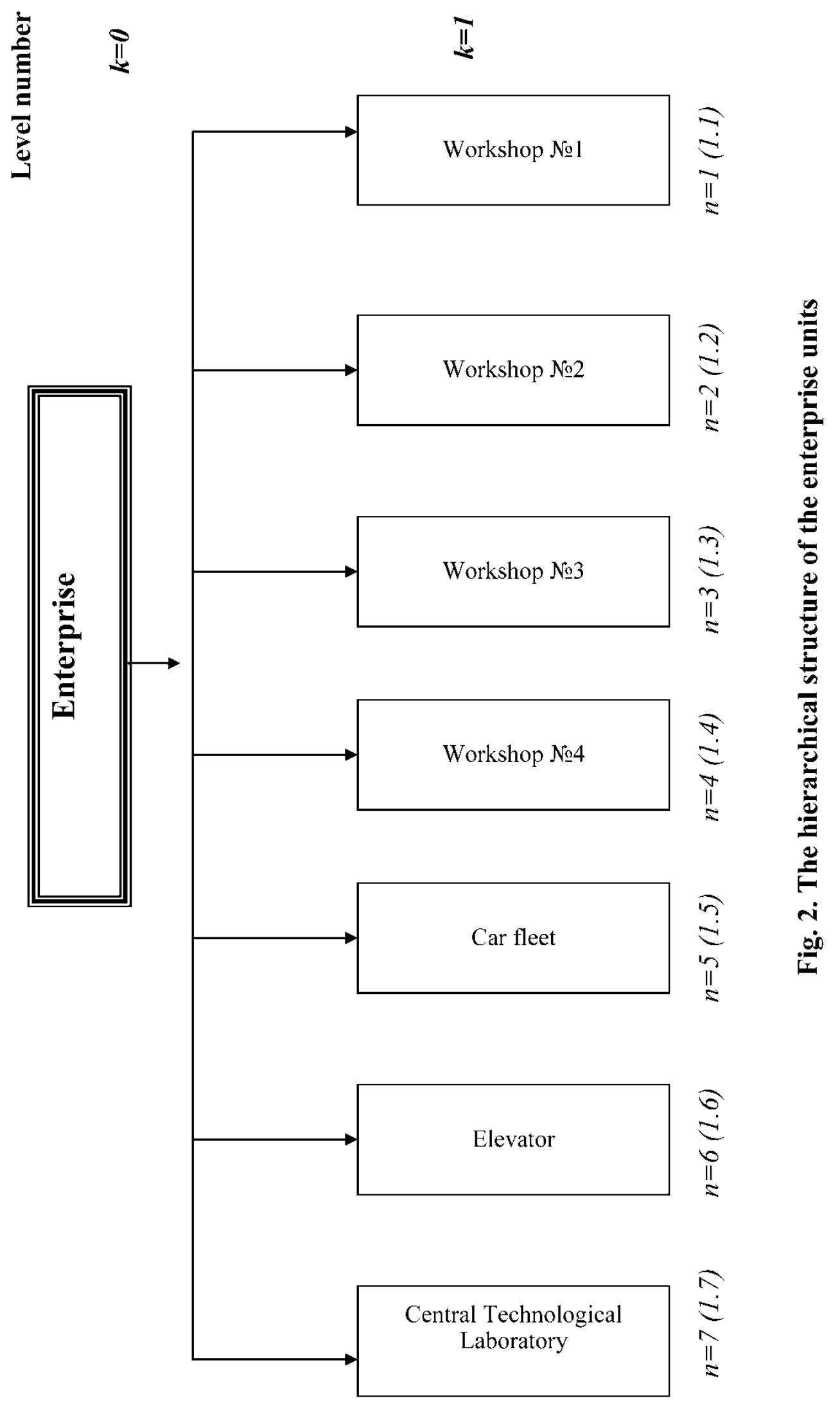


After the classification of production units, management periods, products and resources used to any necessary level, it is possible to determine the production efficiency and the efficiency of use of each of the resources in the production process.

$E_{r i p}^{k n \pi t}-$ an indicator of the cost-effectiveness of the resource $i$ of the subsystem $r$, which is expended for the production of products of type $p$ by unit $(k n)$ for the period д $(\tau t)$.

Each unit $(k n)$ for the period $(\tau t)$ makes products of certain types $p \in P^{k n t}$. For each type of product $p$ a large amount of resources $i$ ( $i \in I_{p}, p \in P^{k n t t}$ ) is consumed. Since the basis of constructing a system of indicators is a comparison of production results with costs, the efficiency of using the resource $i$ of the subsystem $r$ for the production of products of type $p$ in the unit $(k n)$ for the period $(\tau t)$ is determined by the formula ${ }^{7}$ :

$$
E_{r i p}^{k n t t}=\frac{Z_{p}^{k n \pi t}}{Y_{r i p}^{k n \pi t}} .
$$

The given dependence makes it possible to calculate the efficiency of using the resources of any subsystem in the production of each unit for the analyzed period of time.

For example, it is necessary to analyze the process of providing labor resources $(r=1)$ for the production of workshop № $2(k=1, n=2)$ for the first quarter of $2018(\tau=1, t=1)$. In this particular case, the efficiency of providing labor resources is calculated by the formula:

$$
E_{1}^{1211}=\frac{Z^{1211}}{Y_{1}^{1211}} .
$$

The efficiency of using all types of resources in the production process in the $k n$ unit for the period $\tau t$ in this case is calculated by the formula:

$$
E_{R}^{k n \pi t}=\frac{Z^{k n \pi t}}{\sum_{r=1}^{R} Y_{r}^{k n \pi t}} .
$$

\footnotetext{
${ }^{7}$ Безус А.М., Клименюк М.М. Оцінка складності управління як основа удосконалення структури управління театром. Збірник наукових праць : Актуальні культурно-мистещькі проблеми. Київ : ІВЦ Символ-Т, 2001. С. 229-234.
} 
In the same way, it is easy to determine the resource costs of each resource subsystem, all resource subsystems as a whole for an enterprise or for any production unit, or some of them for different time periods. This also applies to production indicators. In order to determine these indicators for resource expenditures and production, it is necessary to summarize their respective components for production units and time periods.

The production efficiency of various types of products is different from each other. To identify the reserves for increasing efficiency in the analysis of production, it is necessary to calculate the indicators of production efficiency of each type of product separately according to the following formula:

$$
E_{p}^{k n t t}=\frac{Z_{p}^{k n \pi t}}{Y_{p}^{k n t t}},
$$

where $Y_{p}$ - full set of resources used to produce products of the type $p$.

The given formulas make it possible to evaluate the performance indicators of the lower level of the system. Since the enterprise management system has a hierarchical structure, the indicator system, which is able to evaluate the activity of the enterprise, must have a multilevel structure.

To simplify, the structure of resources used in production is adopted at a three-level (resource of type $i$, resources of the subsystem $r$, resources of all subsystems $R$ ), and the produced products are adopted at two levels (products of type $p$, number of types $P$ ). Formulas for assessing the effectiveness of the use of resources at all other levels of the hierarchy for production at all levels of the structure are similar to those given.

To assess the effectiveness of the enterprise, it is necessary to check the degree of implementation of the planned state of effectiveness. Based on this, the planned level of efficiency of application of the resource $i$ of the subsystem $r$ for the production of products of type $p$ in the unit $(\mathrm{kn})$ for the period $(\tau t)$ is measured by the indicator of the implementation of the planned production efficiency $\left(A_{e}\right)$ :

$$
A_{e_{r i p}}=\frac{E_{r i p 2}^{k n t t}}{E_{r i p 1}^{k n t t}}
$$

General view of the formula for assessing the implementation of the enterprise plan for the entire period under consideration for the production 
of all types of products at the cost of the necessary resources of all subsystems:

$$
A_{e}=\frac{E_{2}}{E_{1}}
$$

where $E_{1}$ - planned level of process efficiency that is being analyzed; $E_{2}$ - actual level of effectiveness of this process.

Thus, it is possible to evaluate the implementation of the plan by each division of the enterprise for any period of time to ensure the efficient use of resources for the production of products of various levels of their structure.

Based on the definition of efficiency for all existing factors of production, the search for factors that influence the volume of production can be carried out in each of these areas. In the analysis of production, those factors that have the least efficiency value are important, since the influence on these factors can lead to an increase in the efficiency of the whole production ${ }^{8}$.

Based on the decomposition of the control system, the volume of production, in the general case, can be increased either as a result of an increase in the capacity of any production unit, or an increase in the amount of a resource of a certain type, as well as by their combined influence in certain periods of time and management. But at the same time, it is necessary to make a choice only of such factors and such a quantitative change that will provide an intensive path of production development.

To clarify the concept of intensification of production for specific conditions of increasing production volumes due to production factors, it is necessary to consider options for various ways of development of production.

To assess the intensity of production after the introduction of the appropriate option for its development compared with the initial state, it is necessary to introduce a production efficiency index $Q$, which can be calculated for the enterprise as a whole by':

\footnotetext{
8 Клименюк Н.Н. Автоматизированные системы управления предприятиями сборного железобетона. Київ : Вища школа, 1984. 216 с.

9 Безус П.І. Моделювання процесу економічного розвитку виробничого підприємства: автореф. дис. на здобуття наук. ступеня канд. екон. наук : спец. 08.00.11 «Математичні методи, моделі та інформаційні технології в економіці». Київ, 19 с.
} 


$$
Q=\frac{E^{\prime}}{E} .
$$

For any subsystem for the analyzed period of time, formula (14) has the following form:

$$
Q^{k n \pi t}=\frac{E_{p}^{k n \pi t^{\prime}}}{E_{p}^{k n \pi t},}
$$

where $E^{\prime}, E_{p}^{t k n \tau, ~-~ a s s e s s m e n t ~ o f ~ p r o d u c t i o n ~ e f f i c i e n c y ~ a f t e r ~ t h e ~}$ implementation of some production development option;

$E, E_{p}{ }^{t k n \tau}-$ assessment of production efficiency for the implementation of some production development option.

Thus, by introducing an efficiency index, it is possible to determine the intensity of production.

The intensive way of development of production is an option for the development of production, in which, after feasible transformations or innovations, the index of production efficiency gets a value more than one, or, in other words, this option of development of production leads to an increase in the coefficient of production efficiency.

Let us suppose, that the production unit whose activity is being analyzed has passed the selected development option. From the moment of the start of the implementation of this option to the moment of stable output, a period of one year has passed. During this time interval, this production unit increased its output by $\alpha$ times, that is, from value $Z_{p}^{k n \pi t}$ to value $\alpha Z_{p}^{k n \text { zt }}$, while the cost of resources increased proportionally. This means that the efficiency after the implementation of a suitable option for the development of production has not changed and is equal to the initial. ${ }^{10}$

In this case, the production efficiency index is equal to one:

$$
Q=\frac{\alpha \times Z_{p}^{k n t}}{\alpha \times Y_{p}^{k n t}} \div \frac{Z_{p}^{k n t}}{Y_{p}^{k n t t}}=1,
$$

where $\alpha$-coefficient of increase in production.

This method of increasing the volume of production is extensive, that is, increasing the volume of products, with the extensive method of

${ }^{10}$ Безус А.М., Безус П.І. Управління розвитком підприємства: моделі та методи : монографія. Київ : ВПЦ АМУ, 2008. 152 c. 
development corresponds to a proportional increase in the volumes of resources involved in the production process, that is, a proportional increase in the cost of production of this product.

Extensive development of production also includes a method in which an increase in the volume of output corresponds to an increase in the volumes of resources involved in the production process, but in a disproportionate amount, that is, this method leads to an increase in the cost of production of this product, but the efficiency index is less units.

The development of production should be achieved on a fundamentally new basis, based on the comprehensive intensification of production. In this regard, it is necessary to consider another option for the development of production.

Let us suppose, that in order to increase the volume of production, a certain variant of the development of production was carried out, while the volume of production that began to be produced after the transformations increased by $\alpha$ times compared to the initial one, while the total amount of expended resources increased by $\beta$ times, with $\alpha>\beta$ (it is necessary to pay attention to the fact that, for comparison, the amount of resources used and the amount of products received are measured in monetary units).

In this case, the production efficiency after the implementation of the selected option for the development of the enterprise is:

$$
E_{p}^{k n \pi t^{\prime}}=\frac{\alpha \times Z_{p}^{k n t t}}{\beta \times Y_{p}^{k n \imath t}} \neq E_{p}^{k n \pi t}
$$

Thus, after the implemented transformations, the volume of production increased and the amount of expended resources also increased by a certain amount, but the efficiency with this option of increasing production volumes did not remain the same (in the formula, the numerator increased more than the denominator) and when comparing efficiency before and after the transformations, you can determine that:

$$
E_{p}^{k n t^{\prime}}>E_{p}^{k n \pi t} .
$$

In this case, the production efficiency index exceeds one:

$$
Q=\frac{E_{p}^{k n n^{\prime}}}{E_{p}^{k n t}}>1
$$


This method of economic development, aimed at increasing production volumes, is intensive, that is, with an intensive path of development of production, an increase in costs leads to a significantly larger increase in output.

Analyzing the proposed options for the development of production, it can be determined that in the first case under consideration, with a proportional increase in output $Z$ and resource $Y$, the efficiency before and after the transformation remained unchanged $\left(E^{\prime}=E\right)$, in this case, the development was carried out in an extensive way, which is confirmed by the development coefficient, $Q_{1}=\frac{E^{\prime}}{E} \leq 1$. In the second case under consideration, when $E^{\prime} \neq E$, i.e. $E^{\prime}>E$, there is an intensive path of development of production, represented by the coefficient $Q_{2}=\frac{E^{\prime}}{E}>1$.

In order to increase production efficiency among possible options for the development of enterprises, it is necessary to apply only those that provide a significant increase in production intensity.

From the point of view of intensification of production, it is necessary to analyze all the factors involved in production existing in a given production, and select from them those whose impact is most appropriate. To do this, it is necessary to establish patterns that determine the relationship between the volume of production of the enterprise with the identified factors, namely, to determine the function, which has the following general form:

$$
\mathrm{Z}=\mathrm{f}\left(\mathrm{Y}_{\mathrm{r}}\right), r=\overline{1, g},
$$

where $Z$ - volume of manufactured production;

$Y_{r}$ - amount of resource of type $r ; r=\overline{1, g}$.

In order to make this dependence more consistent with the actual conditions of production, it is necessary, along with the quantitative characteristics of the analyzed factors, to take into account their qualitative characteristics, that is, the correspondence of the quantity of all resources necessary for the manufacture of each unit of production. To calculate the indicator of losses from the maintenance of incomplete reserves of resources, it is necessary to calculate the weighted average specific consumption of the $r$ - th resource for the production of all types of products according to the following formula: 


$$
\mathcal{V}_{r}=\frac{\sum_{p=1}^{m} \mathcal{V}_{r p} \cdot Z_{p}}{\sum_{p=1}^{m} Z_{p}} ; r=\overline{1, g},
$$

where $v_{r}$ - weighted average specific consumption of the $r-$ th resource for the production of all types of products;

$v_{r p}$ - expenses of the $r$ - th resource for the production of a unit of production of the $p$ - th type $(p=\overline{1, m})$, i.e. $v_{r p}=\frac{Y_{r p}}{Z_{p}}$;

$Y_{r p}$ - amount of resource of the type $r ; r=\overline{1, g}$, which is necessary for the production of products of the $p$ - th type;

$Z_{p}$ - the planned production volume of the $p$ - th type of products for the period under review.

It is also necessary to calculate the possible total number of products of all types, which could conditionally be obtained from the available quantity of each type of resource $r$ separately, provided that other resources are not constraining, i.e. $Y_{\phi} \geq v_{r} \cdot Z, \phi \neq r ; \phi, r=\overline{1, g}$, then:

$$
\overline{Z_{r}}=\frac{Y_{r}}{\mathcal{V}_{r}} ; r=\overline{1, g},
$$

where $\bar{Z}_{r}$ - the conditional quantity of products that can be obtained from the available quantity of each type of resource $r$ separately, provided that other resources are not constraining;

$Z$ - total production of all types;

$Y_{r}$ - some amount of resource $r$ - type, available for a given period of time (or for the period of time being considered) at the enterprise;

$Y_{\varphi}$ - the amount of all types of resources involved in the production of total output;

$\varphi, r$ - types of resources, and $r$ - is the type of resource that is considered in this case.

Thus, $P$ score can be formed $\left(\overline{Z_{r}}, r=\overline{1, g}\right), p=\overline{1, m}$

possible volumes of production of products of all kinds, which allows us to ensure the available quantity of the $r$-th resource, provided that other resources are not constraining. The quantity of products that can be made from the available quantity of resources at a weighted average specific consumption $v_{r}$, is: 


$$
\bar{Z}=\min _{r}\left\{\bar{Z}_{r}, r=\overline{1, g}\right\} .
$$

If the constraining resource is $r$, then for each resource $r$, where $r \neq r^{\prime}$, after production $(\bar{Z})$, a certain amount of resources will remain unused through incompleteness of existing resource reserves.

In this regard, it is possible to determine the amount of conditional products that would be additionally produced from the leftovers of each resource, and also provided that there are no restrictions on other resources. Thus, the amount of additional conditional products is calculated:

$$
\Delta Z_{r}=\overline{Z_{r}}-\bar{Z} .
$$

Thus, when forecasting production reserves, the inclusion in the function that determines the laws of relations of all factors among themselves indicators of resource completeness is an important condition for the implementation of intensive development of production.

\section{CONCLUSIONS}

Economic development is associated with a change in the structure of the enterprise, the range of products or the direction of its activity requires significant investment. This direction of economic development is extensive. Therefore, subject to limited resources, special attention should be paid to the method of economic development of business entities without attracting investments by identifying and using reserves for each factor of production, which should be preceded by a structuring of the production management system as a basis for determining reserves for increasing production volumes.

Each management task in the implementation of the production development process should be associated with a continuous determination of its effectiveness. Therefore, the set of tasks for determining effectiveness should have an identical multi-level structure. The introduction of a production efficiency index makes it possible to assess the intensity of production after the introduction of an appropriate option for its development compared to the initial.

In the study of the enterprise, along with an analysis of the main characteristics of production factors, it is necessary to use qualitative parameters (an indicator of the completeness of the stock of all necessary resources for manufacturing a unit of production and an indicator of the 
uniformity of the distribution of the completeness of the stock of resources over time), even a slight increase in which leads to an increase in production volumes, however, as an increase in the total stock may not lead to positive changes in production.

\section{SUMMARY}

The work explores the method of economic development of business entities without attracting investment by identifying and using reserves for each production factor. It is determined that, based on the method of decomposition of the management system, the subsystem for managing the provision of the enterprise with resources, it can be divided into smaller elements, each of which may have reserves and which should reflect the actual management tasks. It is proposed to carry out calculations of production efficiency for each type of product, which should be based on a system of indicators that reflect the structure of the enterprise management system as a whole. It is noted that in the study of the enterprise, it is necessary to use the indicator of completeness of the stock of all necessary resources for the manufacture of a unit of production and the uniformity of the distribution of the completeness of the stock of resources over time.

\section{REFERENCES}

1. Статистичний щорічник України за 2016 рік / Державна служба статистики України. Київ : ТОВ «Август Трейд», 2017. 552 с.

2. Безус П.І., Безус А.М. Стратегії економічного розвитку виробничих підприємств. Вісник КНУТД. Серія «Економічні науки». 2016. № 2. С. 80-87.

3. Глушков B.M. Макроэкономические модели и принципы построения ОГАС. Москва : Статистика, 1975. 250 с.

4. Клименюк Н.Н. Алгоритм декомпозиции систем организационного управления. Исследование операщий $u$ ACУ : Республиканский междуведомственный науч. сб., 1985. Вып. 26. С. 97-104.

5. Менеджмент : експрес-підручник / за заг. ред. М.М. Клименюка. Київ : Міленіум, 2017. 174 с.

6. Гавва В.Н. Потенціал підприємства: формування та оцінювання. Київ : ЦНЛ, 2004. 224 с. 
7. Безус А.М., Клименюк М.М. Оцінка складності управління як основа удосконалення структури управління театром. Збірник наукових праџь : Актуальні культурно-мистецькі проблеми. Київ : ІВЦ Символ-Т, 2001. С. 229-234.

8. Клименюк Н.Н. Автоматизированные системы управления предприятиями сборного железобетона. Київ : Вища школа, 1984. $216 \mathrm{c}$.

9. Безус П.І. Моделювання процесу економічного розвитку виробничого підприємства: автореф. дис. на здобуття наук. ступеня канд. екон. наук : спец. 08.00.11 «Математичні методи, моделі та інформаційні технології в економіці». Київ, 19 с.

10. Безус А.М., Безус П.І. Управління розвитком підприємства: моделі та методи : монографія. Київ : ВПЦ АМУ, 2008. 152 с.

\section{Information about the authors:} Bezus P. I.

Ph.D in Economics, Associate Professor, Associate Professor at the Department of Management and International Economic Relations, V. I. Vernadsky Taurida National University 33, John McCain str., Kyiv, 02000, Ukraine 